\title{
Differential phosphorylation of LZ+/LZ- MYPT1 isoforms by PKGla: implication for vascular reactivity
}

\author{
Samantha Yuen*, Ozgur Ogut, Frank V Brozovich \\ From 5th International Conference on cGMP: Generators, Effectors and Therapeutic Implications \\ Halle, Germany. 24-26 June 2011
}

\section{Background}

MLC phosphatase is a trimeric enzyme composed of a catalytic subunit, a 20-kDa subunit of unknown function, and a myosin targeting subunit (MYPT1). During NO stimulation, PKGI $\alpha$ mediated phosphorylation of MYPT1 increases MLC phosphatase activity, which produces a decrease in force. Further, alternative splicing of a 3' exon produces two MYPT1 isoforms, which differ by the presence or absence of a leucine zipper (LZ); a $\mathrm{LZ}+$ MYPT1 isoform is required for PKGIa induced smooth muscle relaxation.

\section{Results}

To examine the influence of MYPT1 structure on the ability of PKGI $\alpha$ to phosphorylate the protein, we used two MYPT1 fragments, which differed only by the presence (MYPT1LZ+) or absence (MYPT1LZ-) of the LZ. Purified PKGI $\alpha$ phosphorylated MYPT1LZ+, but not MYPT1LZ-. Following phosphorylation, MYPT1LZ + predominantly existed as a di-phosphorylated protein, and mass spectrometry identified $S^{668}$ and $S^{695}$ as PKGI $\alpha$-mediated phosphorylation sites. To examine the relative rates of $S^{668}$ vs $S^{695}$ MYPT1 phosphorylation, these residues were mutated to either A or D. The rates of $\mathrm{D}^{668}$ and $\mathrm{A}^{668}$ MYPT1 phosphorylation were similar and slow. The $\mathrm{D}^{695}$ MYPT1 mutant had the highest rate of phosphorylation, while the rate of phosphorylation of the $\mathrm{A}^{695}$ MYPT1 mutant was intermediate between that for the $\mathrm{D}^{695}$ MYPT1 and either $\mathrm{A}^{668}$ or $\mathrm{D}^{668}$ MYPT1.

* Correspondence: brozovich.frank@mayo.edu

Cardiovascular Diseases, Mayo Medical School, Rochester, MN USA

\section{Conclusion}

These results suggest that PKGI $\alpha$-mediated phosphorylation of $S^{695}$ is slower than $S^{668}$, and could suggest that PKGI $\alpha$-mediated phosphorylation of $S^{668}$ is physiologically significant for the regulation of MLC phosphatase activity. Further, MYPT1 structure has an important role in the regulation of vascular tone, and differential tissue expression of LZ+/LZ- MYPT1 isoforms contributes to the diversity in the sensitivity of smooth muscle to $\mathrm{NO}$ mediated vasodilatation.

Published: 1 August 2011

doi:10.1186/1471-2210-11-S1-P78

Cite this article as: Yuen et al:: Differential phosphorylation of LZ+/LZ-

MYPT1 isoforms by PKGl $\alpha$ : implication for vascular reactivity. $B M C$

Pharmacology 2011 11(Suppl 1):P78.

Submit your next manuscript to BioMed Central and take full advantage of:

- Convenient online submission

- Thorough peer review

- No space constraints or color figure charges

- Immediate publication on acceptance

- Inclusion in PubMed, CAS, Scopus and Google Scholar

- Research which is freely available for redistribution 